\title{
Development of Multimedia-Based Learning Models in Fourth Grade English at Amaliyah Sunggal Elementry School
}

\author{
Rizky Mahrani Lubis ${ }^{1, *}$ Efendi Napitupulu² Naeklan Simbolon ${ }^{3}$ \\ ${ }^{1}$ Magister Technology Education, Universitas Negeri Medan, Medan, Indonesia \\ ${ }^{2}$ Magister Technology Education, Universitas Negeri Medan, Medan, Indonesia \\ ${ }^{3}$ Magister Technology Education, Universitas Negeri Medan, Medan, Indonesia \\ *Corresponding. Email: rizkymahrani15@gmail.com
}

\begin{abstract}
This study aims to: (1) To develop English vocabulary learning media on the theme The Beauty of Diversity in My Country, the sub-theme of ethnic and religious diversity in my country based on Multimedia that is appropriate and suitable for use in fourth grade students of SD Amaliyah Sunggal Jalan Tani Asli Sunggal Medan. (2) To determine the effectiveness of the learning outcomes of fourth grade elementary school students in learning English vocabulary by using multimedia rather than learning by using textbooks.

Successful learning in schools can provide optimal results on student learning outcomes, one of which is influenced by learning media. Learning media that is considered to support student learning success is multimedia. This study aims to develop an interactive multimedia-based learning model on English vocabulary at SD Amaliyah Sungal Medan. This study uses a Research and Development approach with the ADDIE model (Analyze, design, dissemination, evaluation]. The research sample is 32 students of SD Amaliyah grade IV. Data collection techniques used tests, and questionnaires. Data were analyzed using descriptive statistics. The results showed that: 1) MERIAH learning media using English learning multimedia can improve student learning outcomes by 48.57. 2) Multimedia learning English is suitable for use in fourth grade elementary school students according to acceptance experts, material experts, and media experts. 3) Students' English learning outcomes after participating in lively learning using English multimedia obtained an average score of 90.78 .
\end{abstract}

Keywords: Learning Outcomes, Multimedia, English.

\section{INTRODUCTION}

Development in the field of education today can be seen from the improvement of the education implementation system and the development of learning which is always sought from time to time as stated in the Law of the Republic of Indonesia Number 20 of 2003 concerning the National Education System which outlines that development in the field of education is an effort to develop the ability and form a dignified national character and civilization in the context of educating the nation's life, aiming to develop the potential of students to become human beings who believe and are devoted to God Almighty, have noble character, are healthy, knowledgeable, capable, creative, independent and become citizens who democratic and accountable (Ministry of National Education, Law No. 20 of 2003: Article 3).

Learning activities in schools are the main activities in improving the quality of national education because through learning it is hoped that educational goals will be achieved in the form of changes in student behavior. In the view of the 2013 Curriculum, learning activities are an educational process that provides opportunities for students to be able to develop all their potential into abilities that are increasingly increasing in terms of attitudes (affective), knowledge (cognitive), and skills (psychomotor). To achieve the quality as designed in the 2013 curriculum document, learning activities should use student-centered principles, develop student creativity, create fun and challenging conditions, contain values such as ethics, aesthetics, logic, and 
kinesthetics, and also provide experiences diverse learning through the application of various learning strategies and methods that are fun, contextual, effective, efficient, and meaningful.

English is a tool for communicating orally and in writing. Communicating is understanding and expressing information, thoughts, feelings, and developing science, technology, and culture. English is a global language that plays a very important role in global interaction and communication along with the progress and competition of globalization. Given the important role of English in the 21st century, the government has set English as a foreign language that must be studied in schools for junior high and high school levels. In contrast to the elementary school level (SD), English language education at the elementary level has been developed as a local content lesson since 1994.

Additional subjects (local content) are usually subjects that are really needed by the school and the surrounding community. Decree of the Minister of Education and Culture No. 060/U/1993 dated February 25, 1993 regarding the English program given as a local content subject for elementary school students, and can be started in fourth grade (4). The curriculum for local content subjects was not developed by the Ministry of National Education Curriculum Center but was developed at the provincial level. According to guidelines from the government, English language education can be carried out starting from the 4th grade of elementary school. Determination of local content subjects such as English lessons in elementary schools is the right of the school's authority, for private elementary schools as well as for public elementary schools.

The objectives of teaching English in elementary schools include (1) Listening, namely understanding very simple instructions, information, and stories conveyed orally in the context of the classroom, school, and the surrounding environment. (2) Speaking, namely expressing meaning orally in very simple interpersonal and transactional discourses in the form of instructions and information in the context of class, school, and the surrounding environment. (3) Reading, namely reading aloud and understanding the meaning in instructions, information, short functional texts, and very simple illustrated descriptive texts that are delivered in writing in the context of class, school, and the surrounding environment. (4) Writing, namely writing very simple words, expressions, and short functional texts with proper spelling and punctuation. The limited understanding of English vocabulary results in delays in the achievement of language competence. In acquiring language, both mother tongue and foreign language, it is necessary to have a process of mastering the language which is done by children naturally (naturally) and learning in the classroom, namely students who are taught by the teacher.

Learning English in elementary school should be simple, easy, and fun. Learning should not burden students because it will greatly affect student achievement. Learning should be presented in a visual form because it is easier to absorb and remember than just a narrative. Therefore, it is necessary to implement a delivery of information through the paradigm of learning by hearing, hearing and doing, for example by utilizing multimedia technology. This is the basis for consideration by researchers to develop interesting, effective and fun English learning media for elementary school students. The lack of interest in students' learning is the main problem that occurs in the learning process at Latief's school (2017), the lack of media use in the learning process, and the teacher only uses the teacher's book and the student's book as a source of learning. Then the problem that often occurs in the learning process is that it does not involve students to be able to provide fun learning and critical thinking through learning while playing.

According to Musfiqon (2016), there are several criteria that must be considered in the selection of learning media, as follows; a) learning objectives are in accordance with what is to be achieved in the learning process; b) learning content supports facts, concepts, principles and generalizations of the lesson; c) media are practical, flexible and durable; d) skilled teachers in using learning media; e) target grouping of learning media; f) technical quality.

Another problem is in the learning process, especially in the thematic learning of the sub-theme of the beauty of my country's cultural diversity. Preservation of local cultural customs carried out by the local community is intended to maintain it well down to the children to keep the culture so as not to forget its origin. In the learning process, teachers rarely use learning media to introduce existing cultural diversity, making it difficult for students to learn thematically (Fitriyawany, 2013).

Based on this policy, stakeholders (Principals and School Committees), teachers and school residents also support the holding of an English learning program at SD Amaliyah Sunggal Medan. The development of the English learning process that took place at SD Amaliyah Sunggal Medan, from year to year did not have a significant development. This can be seen in the average grade of English for class IV (four) which is still low. In the last 3 years, student learning outcomes for English lessons have not been able to reach the KKM score. From the data obtained by the researcher in the observation of the previous analysis, it is known from 32 students in the fourth grade of elementary school that $40 \%$ of students have difficulty writing vocabulary (vocabulary). Students stated that it was difficult to 
write English vocabulary because the writing of English vocabulary was not the same as the pronunciation of the vocabulary. The cause of the difficulties experienced by students is because their understanding of English is still low.

The results of observations made by researchers through a questionnaire test of 32 fourth grade students as a sample and 15 teachers at SD Amaliyah Sunggal Medan Jalan Tani Asli showed that $100 \%$ of students and $75 \%$ of teachers teaching at SD Amaliyah Sunggal Medan needed media. learning with multimedia video animation which is an alternative learning resource as an effort to help the learning process more interesting to improve student learning outcomes. Amaliyah Sunggal Medan. The researcher also uses the Research and Development Approach with the ADDIE model in the vocabulary lesson of the sub-theme The Beauty of Cultural Diversity in the Country.

\subsection{The Nature of Learning and Learning}

The nature of learning is one of the most important activities in the whole educational process is learning activities. The success or failure of achieving educational goals depends a lot on how the learning process can take place effectively. Besides that, the meaning of a teacher on the notion of learning will greatly affect the way teachers carry out learning activities which ultimately affect the intellectual, psychological, and biological aspects of students. According to Piaget (1966) educational experience must be built around the learner's cognitive structure. So optimal education requires a challenging experience for the learner so that the process of assimilation and accommodation can result in intellectual growth.

Gagne, Briggs and Wager (1992:18) state that a person's learning process can be influenced by the learner's own internal factors and external factors, namely the setting of learning conditions. The learning process occurs because the synergies of short-term and long-term memory are activated through the creation of external factors, namely learning or the learning environment. Through their senses, students can absorb material differently. The teacher directs that information processing for long-term memory can run smoothly. Based on some of the opinions above, it can be concluded that what is meant by learning is a change in behavior that is influenced by instrumental factors, environmental factors, and individual conditions. So that the individual's efforts can produce better results.

According to Sumiati (2007:176) learning activities are activities that involve students in mental and physical processes through interactions between students, students and teachers, the environment, and other learning resources in order to achieve basic competencies. Learning activities are designed to provide a student learning experience. Wenger (1998) says, "learning is not an activity, something that a person does when he is not doing other activities. Learning is also not something that one stops doing. Moreover, learning can occur anywhere and at different levels individually, collectively, or socially.

\subsection{The Nature of Learning Multimedia}

Understanding Multimedia Learning Multimedia comes from the Latin word multi meaning many or various, medium in Latin means an intermediary or an intermediary used to deliver or deliver something such as mass communication such as newspapers, magazines or television. So in simple terms, multimedia is defined as a combination of text, graphics, sound, video and animation that produces high performance and interactiveness. Multimedia systems consist of traditional media in combination or combined with computers as images of text, images, graphics, sound and video. The term multimedia is described as an application to combine various media to affect the level of education.

Multimedia is a combination of computer and video, or multimedia is a combination of sound, images and text. In general, multimedia is defined as a combination of text, images, graphic art, sound and video. The resulting information has a high interactive communication, meaning that information is not only seen as a printed result, but can be heard, forming simulations and animations that can arouse appetite and have a high graphic art value in its presentation. So based on the various opinions of the experts above, the researcher concludes that multimedia is a unique and very powerful combination of media because it contains visual, video and sound elements that can be combined with creative stra The advantage of multimedia is that it attracts the senses and attracts interest because it is a combination of sight, sound and movement. So, what is meant by interactive learning media is the media used in the learning process as a channel of messages between teachers and students that can be controlled by both teachers and students so as to allow interaction between teachers, media and students so that teaching objectives are achieved. a tool used by people (in this case the teacher) to convey messages to students. According to Hamzah and Nina (2002) describe a number of media contributions in learning activities, including: (1) the presentation of teaching materials becomes more standard, (2) learning activities become easier. The most dominant learning approach in interactive media-based learning is the constructivism learning approach. (Winkel, 2002).tegies to produce attraction.

According to the constructivist paradigm, science is temporary in relation to developments mediated both socially and culturally, so it tends to be subjective. Learning according to this view is more a process of self-regulation in resolving cognitive conflicts that often 
arise through concrete experience, collaborative discourse and interpretation. Learning is an activity of active students to build their knowledge. Students themselves are responsible for events and learning outcomes. Suparno (2001) explains the same thing that according to the constructivism view learning is an active process and knowledge cannot be received from outside or from others, it is students who build their own knowledge, find meaning for themselves what they learn by adjusting concepts and ideas. new ideas with the framework of thinking they already have in mind.

Hamalik as quoted by Arsyad (2002) suggests that the use of teaching media in the teaching and learning process can generate new desires and interests, generate motivation and stimulation of learning activities and even bring psychological effects on students. The use of learning media at the learning orientation stage will greatly help the effectiveness of the learning process and the delivery of messages and lesson content at that time. In addition to arousing students' motivation and interest, learning media can also help students improve understanding, present data in an attractive and reliable way, facilitate data interpretation and condense information.

According to Wood (2001) the use of multimedia learning has the potential to improve vocabulary learning. In multimedia learning can be presented in the form of games, hyperlinks, hypertext, and animation. Game forms can provide external stimulation and display a variety of graphic forms. The hyperlink form gives students the opportunity to acquire new words in a variety of contexts through quick access to the text and graphics students want. The form of hypertext allows students to click on the desired words to hear their pronunciation and increase understanding of the new words being learned. Meanwhile, animation can improve vocabulary learning when combined with informative and interesting narration.

Based on the statements of some of the media experts, it can be concluded that the use of media can increase motivation, stimulation and make it easier for students to understand the material presented and can be used by teachers as teaching aids to improve the quality of active and interactive students so that they can support smooth activities. learning in schools in achieving learning objectives.

\subsection{The Nature of English Vocabulary Definition of Vocabulary}

The essence of the ability to master vocabulary is very important in achieving language mastery, the more vocabulary a person has, the more ideas and ideas a person will master. And in general, vocabulary can be interpreted as a vocabulary. Vocabulary is a collection of words that are owned by a language and give meaning when we use that language.
Vocabulary Mastery is a measure of a person's understanding of the vocabulary of a language and his ability to use that vocabulary both orally and in writing. Mastery of vocabulary is part of mastery of language because if someone masters language, it means that person masters vocabulary. The benefits of mastering vocabulary are: (a) with a lot of vocabulary, you can quickly use words that are in accordance with what you want in certain situations, (b) be able to examine the contents of the reading with the vocabulary you have and can use and examine the contents of the reading carefully. comprehensive and detailed, (c) changing the life status of students, with the vocabulary possessed by students gaining wise and broad experience.

The types of vocabulary that exist are main words and function words. Children master the main vocabulary first because it consists of nouns (nouns), verbs (verbs) and adjectives (adjectives). Of the three main vocabularies, children are easier to master nouns because they are more real (concrete).

According to Tarigan (1997) vocabulary in addition to increasing the quantity and quality of students' vocabulary, but can also aim to: a) improve students' living standards, b) increase the level of students' mental abilities, c) improve students' conceptual development, d) sharpen the learning process. students' critical thinking, and e) broaden the horizons of students' views of life.

\subsubsection{Aspects of English Language Skills}

Richard (2007:) which states that, English is the language of globalization, international communication, trade and trade media, pop culture, different motivations for learning, it comes to play the language. So, it is important for people to learn English, because English is used in every aspect of people's lives.

Brown (1994) said that learning is often considered as a translation of the term "instructional" is the process of interaction of students with educators and learning resources in a learning environment. Learning is described by Gagne and Briggs in Brown, as a person's effort whose goal is to help people learn. Therefore, there are five assumptions that support learning, namely (1) learning must be planned in order to facilitate student learning, (2) both short and long-term phases are included in the learning design, (3) learning planning should not be careless and not solely providing a nurturing environment, (4) learning efforts must be designed with a systems approach, and (5) learning must be developed based on knowledge of how the person learns. 
Furthermore, Gagne and Briggs in Brown (1994:910) explain that there are several characteristics of learning, namely (1) attracting attention so that students are ready to accept the lesson, (2) informing the purpose of the lesson, (3) stimulating memory for previous teachings. , (4) presentation of teaching materials and learning aids (5) providing learning guidance, (6) generating the emergence of performance in learning, (7) providing feedback, (8) assessing performance, and (9) strengthening retention and transfer study.

\subsubsection{Models Related to Festive Model}

Thobroni (2015:55) behavioristic learning theory is a theory about changes in behavior as a result of experience initiated by Gagne. Behaviorism is a view which holds that behavior should be explained through experiential experiences, not by mental processes. According to behaviorists, behavior is everything we do and can be seen directly. According to Santrock (2015) mental processes are defined as thoughts, feelings, and motives that we experience but cannot be seen by others. Learning here is a change in behavior that occurs based on the Stimulus-Response (S-R) paradigm, which is a process of giving a certain response to a stimulus that comes from outside. Behavioristic learning theory explains learning is a change in behavior that can be observed, measured, and assessed concretely. Change occurs through stimuli (stimulants) that cause a reactive behavior relationship (response) based on mechanistic laws.

Thorndike (1912) identified three (3) laws of learning to explain this process, as follows: First, the law of readiness. The law of readiness, namely the more ready an organism is to obtain a change in behavior, the implementation of that behavior will lead to individual satisfaction. so the association tends to be strengthened. Second, the law of exercise, the more often the behavior is trained or used, the stronger the association. In principle, the connection between conditions (which are stimulants) and actions will become stronger due to practice, but will weaken if the connection between the two is not continued or terminated. The third law of effect (law of effect) is the law of results, namely the stimulus-response relationship tends to be strengthened if the result is pleasant and tends to be weakened if the result is unsatisfactory.

From his research Piaget concluded that children's cognitive development goes through a fixed sequence. The pattern of operations that children can do can be said to be a level or stage. Schunk (2012) each level or stage is determined by how children see their world. Piaget stated that a child progresses through four stages of cognitive development, namely: the sensori-motor stage, pre-operational, concrete operations, and formal operations Susanto (2016). The speed of development of each individual through the sequence of each of these stages is different and no individual skips any of these stages.
According to Thobroni (2015) the stages of cognitive development are described as follows:

- Sensory Motor Stage, At the sensory motor stage (0 - 2 years), a child learns to develop and organize physical and mental activities into a series of meaningful actions. Dahar (2011) added that during this period, children regulate their nature with their senses (sensory) and actions (motor).

- Pre-Operational Stage, At the pre-operational stage (2-7 years), a child is still very influenced by special things obtained from the experience of using the senses so that he has not been able to see relationships and conclude something consistently.

- Concrete Operational Stage, At the concrete operational stage (7-11 years), a child can make inferences from something in a real situation or by using concrete objects, and is able to consider two aspects of a real situation together.

- Formal Operational Stage, At the formal operational stage (11 years and over), the ability to reason abstractly increases so that a person is able to think deductively. At this stage, one is able to consider several aspects of a situation together.

According to Dahar (2011) all children go through each level, but at different speeds. The order of intellectual development is the same for all children. The structure for the previous levels is integrated and included as part of the subsequent levels.

Constructivism as a description of human cognitive is often associated with pedagogical approaches that promote learning by doing. According to this theory, the formation of knowledge occurs as a result of human construction of the reality it faces. In later developments, this theory was influenced by psychological disciplines, especially Piaget's cognitive psychology which deals with psychological mechanisms that encourage the formation of knowledge.

The following are Piaget's three main postulates in relation to the stage of intellectual development or the stage of development of cognitive constructivism or also known as the stage of mental development, namely as follows:

- Intellectual development occurs through successive stages that always occur in the same order. Every human being will experience these sequences and in the same order.

- The stages are defined as a cluster of mental operations (sequencing, retention, grouping, hypothesis making and drawing conclusions) that indicate the presence of intellectual behavior.

- Movement through these stages is complemented by equilibration, a developmental process that describes the interaction between experience (assimilation) and the cognitive structures that arise (accommodation)

Furthermore, Piaget, who is known as a constructivist, asserts that knowledge is built in the 
child's mind through assimilation and accommodation. Assimilation is the absorption of new information in the mind. Thobroni (2015:92-95). While accommodation is rearranging the structure of the mind because of the new information so that the information has a place.

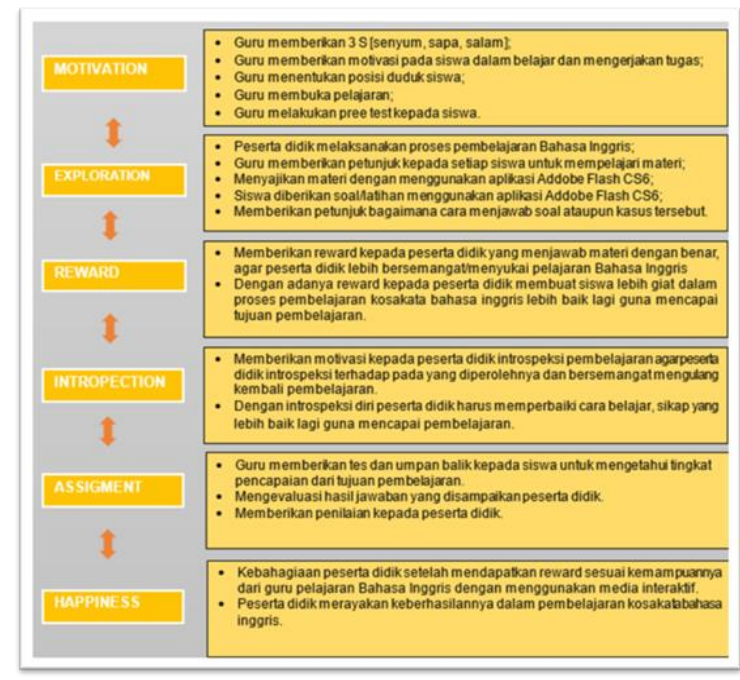

Figure 1. Syntax of the "MERIAH" Learning Model

\section{METHOD}

Research on the development of this Multimediabased learning model was carried out at SD Amaliyah Sunggal Medan which is located on Jalan Tani Asli for the 2020/2021 school year. The development procedure consists of: Preliminary Study, Planning and Modeling Phase, Validation Test, Model Test, In the individual trial sample of 3 students, the small group trial sample of 9 students and the main trial sample there are 32 students. The data are as follows: Questionnaire, Learning Outcome Test, Observation and Documentation. The data analysis technique used is descriptive and inferential techniques. Descriptive technique is a statistic that is used to analyze data by describing the data that has been collected as it is without intending to make generally accepted conclusions or generalizations. The data analysis technique used is descriptive and inferential technique Descriptive technique is a statistic used to analyze data by describing the data that has been collected as it is without intending to make generally accepted conclusions or generalizations. Inferential technique is a statistical technique for analyzing data sample data and the results are applied to the population the probability of error and truth (belief). The steps of the data analysis technique are:."

\section{RESULTS AND DISCUSSION}

\subsection{Preliminary Study Analysis Stage}

The results of the researchers' observations, learning English in elementary schools so far is still conventional. In teaching the teacher only relies on the classical lecture method. Teachers use less supporting media other than books. This learning method does not meet the principles of effective learning and does not empower the potential of students.

It can be concluded that the presence of multimediabased learning is very useful in developing learning materials that are less attractive so that it creates motivation in learning activities.

In addition, the researchers also conducted a pretest to the students to find out the students' mastery in learning English subjects. Based on the results of the pretest, it can be presented as follows:

Table 1. Students' English Preetest Results

\begin{tabular}{|r|l|c|}
\hline \multicolumn{1}{|l|}{ No } & Description & Score \\
\hline 1 & Total & 1835 \\
\hline 2 & Maximum & 72.5 \\
\hline 3 & Minimum & 42.5 \\
\hline 4 & Average & 57.34 \\
\hline 5 & \% Complete & 0.00 \\
\hline
\end{tabular}

The data above shows that the pretest conducted on 32 students on English learning materials obtained a total score of 1835 , a maximum score of 72.5 , a minimum score of 42.5 , an average of 57.34 , with a completeness of $0.00 \%$. This shows that students' English learning outcomes are still low, and efforts are needed to improve the English learning process. Where these efforts can be carried out through learning with the MERIA model [[Motivation, Exploration, Reward, Implementation, Assessment, Happiness]. Learning with the MERIAH model was also developed using learning media.

\subsubsection{Learning Media Design Stage Animation Making}

At this stage, the researchers made preparations to make an animated English learning video, so the steps the researchers took were:

1) Open Photoshop software;

2) Creating teacher image animations;

3) Creating an animated picture of the house area;

4) Create an animated picture of a regional house;

5) Create animated pictures of regional food types;

6) Creating classroom animations;

7) Save all animated images in PNG/GIF format.

An example of an animated image that has been created can be seen in the following image: 

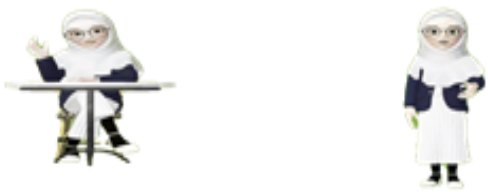

Figure 2. Animated English Teacher in PNG/GIF format

a. Storyboarding

At this stage, the researcher continued the steps that had been prepared previously. Where at this stage the researcher performs the following steps:

1) Opening the 2013 version of Microsoft Powerpoint Office;

2) Set Layout in powerpoint;

3) Inserting pre-prepared animated images in powerpoint;

4) Set the image that has been inserted in powerpoint;

5) Provide animation effects, sound effects, and duration on objects that have been set;

6) Add text to the Slide;

7) Save the file in the form of powerpoint;

8) Save the file in the form of an animated video [MP4].

An overview of the powerpoint creation process before it is saved in MP4 format can be seen in the following image:

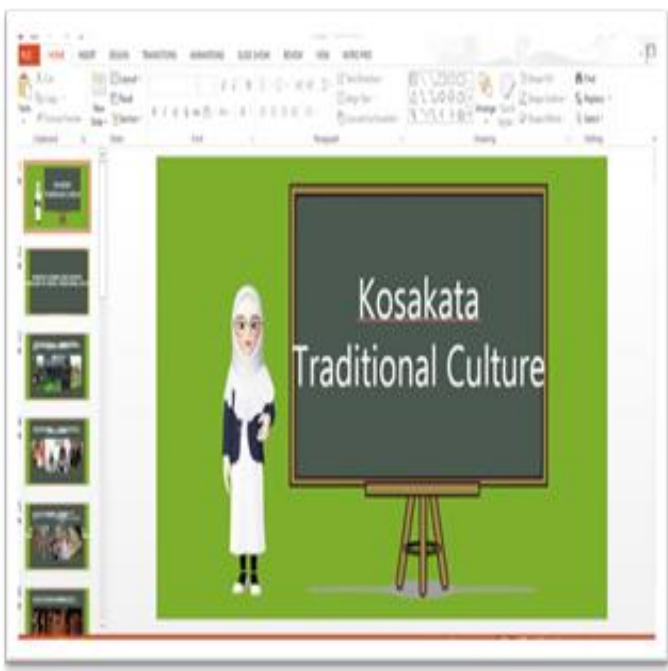

Figure 3. Animation of English Learning in Powerpoint Form

Then, the ready-to-use English learning video in MP4 format can be seen in the following image:

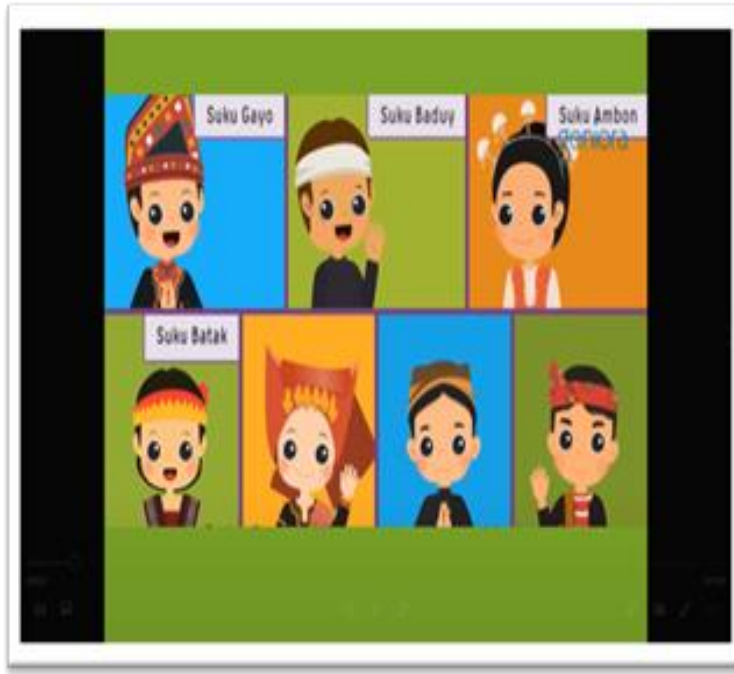

Figure 4. Animated English Learning in MP4 Format

In the trial, the researcher conducted an expert review of the previously prepared learning media. Where the researchers asked media experts, material experts, and design experts for the learning media that had been prepared. At the stage of the results of the review carried out by acceptance experts about the English learning media that have been prepared, the aspects of guidance and information get a score of 20 or $100 \%$, media materials get a score of 60 or $92.31 \%$, evaluations of 24 or $96 \%$, design and media facilities 46 or $92 \%$, pedagogical effect 23 or $92 \%$. According to multimedia experts, scores on guides and information 15 or $100 \%$, software operation 45 or $90 \%$, systematics, aesthetics, and media principles 33 or $94.29 \%$, narrative quality and $100 \%$ audio, video and/or animation quality 17 or $85 \%$, multimedia design principles 23 or $65.71 \%$.

According to the results of a review conducted by media experts, the scores for guidance and information were 23 or $92 \%$, for media materials 56 or $93.33 \%$, and evaluations 36 or $90 \%$. Thus, it can be seen that the English learning media materials that have been prepared are suitable to be used as English learning media for grade IV SD. According to multimedia experts, the score on guides and information is 15 or $100 \%$, software operations 45 or $90 \%$, systematics, aesthetics, and media principles 33 or $94.29 \%$, narration and audio quality $100 \%$, video and/or animation quality 17 or $85 \%$, multimedia design principles 23 or 65.7 . It can be seen that the total score obtained by 3 students who used The learning media that have been prepared obtained a total score of 262.5, a maximum score of 92.5 , a minimum score of 82.5 , an average of 87.50 , and was declared complete 100 . The results of trials conducted on three students showed $100 \%$ completeness. Therefore, the prepared English learning media is suitable for individual use. The small group trial showed that the total score was 762.5, the maximum score was 87.5 , the minimum score was 82.5 , the average was 84.72 , and the completeness was $100 \%$. Thus, it can be stated that the learning media prepared 
are suitable for use in small groups as a medium for learning English.

\subsubsection{Final Stage Evaluation}

a. Field Trial/Large Group

Table 2. Field Trial/Large Group [32 students]

\begin{tabular}{|l|l|l|}
\hline No & Description & Score \\
\hline 1 & Total & 2905 \\
\hline 2 & Maximum & 97.5 \\
\hline 3 & Minimum & 87.5 \\
\hline 4 & Average & 90.78 \\
\hline 5 & \% Complete & 100 \\
\hline
\end{tabular}

The table above shows that the total score is 2905 , the maximum score is 97.5 , the minimum score is 87.5 , the average is 90.87 , and the completeness is $100 \%$.

The results of trials conducted on large groups showed completeness as much as $100 \%$, therefore the English learning media prepared were suitable for use on students individually, in small groups, and also in large groups.

\subsection{Description of Research Data}

The research data described are the scores obtained by students during the pree test, and also the scores obtained by students during large group trials or researchers call the posttest.

Table 3. Description of Research Data

\begin{tabular}{|c|c|c|c|}
\hline & & Preetest & Big team test \\
\hline $\mathrm{N}$ & Valid & 32 & 32 \\
\hline & Missing & 0 & 0 \\
\hline $\mathrm{Me}$ & & 57.34 & 90.78 \\
\hline & & 57.50 & 87.50 \\
\hline Mo & & 58 & 88 \\
\hline & & 7.041 & 3.937 \\
\hline & & 49.572 & 15.499 \\
\hline & & 30 & 10 \\
\hline & & 43 & 88 \\
\hline & & 73 & 98 \\
\hline Sul & & 1835 & 2905 \\
\hline
\end{tabular}

The table above shows that for the pree test, the average score was 57.34, up to 7.041, the minimum score was 43 , the maximum score was 73 , and the total score was 1835 . Meanwhile, for the post test or large group trial, the average score was 90,78 , up to 3,937 , a minimum score of 88 , a maximum score of 98 , and a total score of 2905. This proves a significant improvement in student learning outcomes after learning English using English language learning multimedia prepared by researchers. The homogeneity test was carried out in order to determine whether the two data obtained had homogeneous criteria and characters. The test carried out is using the Leven test with the criteria if sig $>0.05$ then the data is declared homogeneous, or vice versa. For more details can be seen in the following table.

Table 4. Test of Homogeneity of Variances

\begin{tabular}{|c|c|c|c|}
\hline $\begin{array}{c}\text { Levene } \\
\text { Statistic }\end{array}$ & $d f 1$ & $d f 2$ & Sig. \\
\hline 4.776 & 1 & 62 & .330 \\
\hline
\end{tabular}

Homogeneity test

The table above shows that the value of sig. $0.330>$ 0.05 . Therefore, it can be concluded that the data obtained have high homogeneity.

Hypothesis testing

Hypothesis testing was conducted to determine the differences in learning outcomes obtained by students through the results of the pre test and the results of the post test. The test carried out is the $t$ test, with the criteria if the value of sig. $<0.05$, it can be stated that there is an increase in student learning outcomes after participating in learning using multimedia.

Based on data analysis, it can be seen that the value of sig. $0.000<0.05$. Therefore, it can be concluded that the hypothesis is accepted. This means that there is a significant increase in student learning outcomes after participating in learning using multimedia and the MERIAH model. The increase in student learning outcomes on average is 48.65 .

MERIAH learning model [Motivation, Exploration, Reward, Implementation, Assessment, Happiness], which is implemented using English learning multimedia can significantly improve student learning outcomes with an average increase of 48.65 learning outcomes. The lively learning model is designed and implemented using English learning multimedia which is designed and previously reviewed by several experts [acceptance, material, and multimedia]. This is in accordance with the results of several previous studies that are considered relevant.

Research by Sihombing, Farihah and Efendi Napitupulu (2018). The result is the validation of the developed interactive media shows that the views of the display media presentation materials, and media materials on interactive learning media are $87 \%$ with a 
very good category. The results of the validation and instructional design on energy conversion learning developed were $84 \%$ of the design quality with a very good category. Third, the response from individual students is $90 \%$, the response from small groups is $87 \%$, the field trial is $81 \%$, all the results are very good.

Purwanti Research (2015). The results showed that the use of learning animation video media with the ADDIE Model made the perception of learning more positive and more interesting. The average score of students increased from the previous average of 59.19 to 81.48 . So that the use of interactive multimedia-based learning media is very effective in learning.

\section{CONCLUSION}

After conducting a data description and analysis of research results, it can be concluded that:

1. MERIAH learning media using English learning multimedia can improve student learning outcomes by 48.57 .

2. Multimedia learning English is suitable for use in fourth grade elementary school students according to acceptance experts, material experts, and media experts.

3. Hasil belajar bahasa inggris siswa setelah mengikuti pembelajaran meriah dengan menggunakan multimedia bahasa inggris memperoleh skor rata-rata 90,78.

\section{ACKNOWLEDGMENT}

First and foremost, I would like to show my deepest gratitude to my teachers and professors in my university, who have provided me with valuable guidance in every stage of the writing of this thesis. Further, I would like to thank all my friends and roommates for their encouragement and support. Without all their enlightening instruction and impressive kindness, I could not have completed my thesis.

\section{REFERENCES}

[1] Peraturan Pemerintah Republik Indonesia No. 19 tahun 2005 Tentang Standart Nasional Pendidikan

[2] Permendiknas No 41Tahun 2007 tentang Standar Proses Untuk Satuan Pendidikan Dasar dan Menengah.

[3] Gagne, R.M., Briggs L.J., \& Wager W.W. (1992). "Principles of Intructional Design". Fort Worth: Harcourt Brace Jovanovich College

[4] Arsyad, Azhar. 2015. "Media Pembelajaran". Jakarta: Rajawali Pers

[5] Hamalik, O. (2006). Media Pendidikan, Cetakan Ke-7. Bandung: Penerbit Citra Bakti
[6] Wood, J. (2001). “Can software support children's vocabulary development?" [versi elektronik]. Journal of Language Learning \& Technology, 5, 166-265.

[7] Rusman, (2012). Model-model Pembelajaran: Mengembangkan Profesionalisme Guru. Raja Grafindo Persada, Jakarta

[8] Tarigan, H. G. (1994). "Menulis Sebagai Suatu Keterampilan Berbahasa". Bandung: Angkasa. Jurnal Cakrawala Pendas, Volume I, No. 2 Juli 2015

[9] Richard. JC (2007). "Refleksi Pribadi”. Singapura: SEAMEO Regional Pusat Bahasa. Edukasi: Jurnal Pendidikan dan Pengajaran 2(2), 107-120. Publish http://jurnal.radenfatah.ac.id/index.php/edukasi/arti cle/view/602

[10] Brown, H. Douglas.1994. Teaching by Principles: An Interactive Approach to Language Pedagogy. New Jersey: Pren Inc.

[11] Gagne, R.M. (1984). "Kondisi Belajar dan Teori Pembelajaran". Terjemahan oleh Munandir dan Handy Kartawinata. 1990. Departemen Pendidikan dan Kebudayaan Direktorat Jenderal Pendidikan Tinggi Pusat Antar Universitas.

[12] Trim, J L M (Ed.) (2001) Common European Framework of Reference for languages: learning, teaching and assessment. User Guide, Strasbourg: Council of Europe, available online: http://www.coe.int/t/DG4/Portfolio/documents/Gui de-for-Users-April02.doc

[13] ALTE Handbook of Language Examinations and Examination Systems 1998 ALTE web site: www.alte.org

[14] Sudijono, Anas. (2005) Pengantar Evaluasi Pendidikan, Jakarta: Raja Grafindo Persada. 